\title{
CONTACT BLEPHAROCONJUNCTIVITIS DUE TO BLACK HENNA - A CASE REPORT
}

\section{ALICJA PAS-WYROŚLAK ${ }^{1}$, MARTA WISZNIEWSKA², BEATA KRĘCISZ ${ }^{3}$, DOMINIKA ŚWIERCZYŃSKA- MACHURA $^{3}$, CEZARY PALCZYŃSKII ${ }^{2,3}$, and JOLANTA WALUSIAK-SKORUPA ${ }^{2}$}

${ }^{1}$ Nofer Institute of Occupational Medicine, Łódź, Poland

Out-patient Clinic of Occupational Diseases

${ }^{2}$ Nofer Institute of Occupational Medicine, Łódź, Poland

Department of Occupational Diseases and Toxicology

${ }^{3}$ Nofer Institute of Occupational Medicine, Łódź, Poland

Centre of Occupational Allergy and Environmental Health

\begin{abstract}
Para-phenylenediamine (PPD) can induce immediate or - more often - delayed hypersensitivity. We report the case of 48-year old female admitted to the out-patient allergy clinic a day after her visit in a beauty parlour, where she had her eyelashes and eyebrows dyed with henna. Physical examination revealed prominent edema of the upper part of the face including forehead, cheeks and eyes causing severe narrowing of the palpebral chink. Skin prick tests (SPT) with common allergens were positive for Dermatophagoides pteronyssinus, Dermatophagoides farinae and moulds, while the SPT with PPD was negative. Patch test to PPD was positive. Further investigations revealed eosinophilia in the tear fluid. To our knowledge, this is the first case of PPD-induced contact blepharoconjunctivitis (CB) with concomitant increased eosinophilia in the tear fluid.
\end{abstract}

Key words:

Contact blepharoconjunctivitis, Eosinophils, Henna, Tears

\section{INTRODUCTION}

Henna is a natural dye extracted from the dried and powdered leaves of mignonette tree (Lawsonia inermis). It has been used since the antiquity to dye eyebrows, eyelashes, hair, nails and skin. For eyebrow or eyelash henna, various tints in combination with $3 \%$ hydrogen peroxide are used. Black henna contains additives, mainly coal tar, or para-phenylenediamine (PPD). PPD could be found in hair dyes, temporary tattoos, textile dyes and pigments, also in photographic film developers. It can induce immediate or - more often - delayed hypersensitivity. Contact blepharoconjunctivitis (CB) is mainly a Th-lymphocyte mediated hypersensitivity response that involves the conjunctiva, eyelids and periocular skin, caused by ophthalmic drugs or cosmetic agents.

\section{CASE REPORT}

We report the case of 48-year old, smoking female admitted to the out-patients allergy clinic a day after her visit in a beauty parlour, where she had her eyelashes and eyebrows dyed with henna. She had earlier undergone such

Received: October 25, 2011. Accepted: December 30, 2011.

Address reprint request to J. Walusiak-Skorupa, Department of Occupational Diseases and Toxicology, Nofer Institute of Occupational Medicine, św. Teresy 8 , 91-348 Łódź, Poland (e-mail: jolantaw@imp.lodz.pl). 
procedures many times without any side-effects. During the night hours she developed stinging of eyelids, eye burning and tearing. Despite rinsing the eye with cool water and applying cold compresses, symptoms did not retreat. Additionally, swelling of the eyelids and conjunctiva occurred. Anamnesis revealed also personal and family history of atopy - periodic urticarial skin symptoms after eating tomatoes, citrus fruit and chocolate. However, she had never been treated for allergy.

Since an allergy reaction to PPD was suspected, the diagnostic procedures like skin prick tests (SPT), total serum IgE measurement as well as conjunctival tear fluid examination were performed, followed by suitable treatment. Systemic (loratadinum $10 \mathrm{mg}$ once a day for 14 days) and ophthalmic topical antiallergic treatment (5\% loteprednol etabonate 2 drops four times a day for 7 days and 1 drop four times a day for next 7 days; $0.025 \%$ ketotifen 1 drop 2 times a day for 14 days; fludrocortisone $0.1 \%$ unguentum ophtalmicum 3 times a day for 14 days) was applied. The eye symptoms started to recede after three days, and disappeared after 2 weeks. Patch tests to PPD and control conjunctival tear fluid examination were performed after the ocular symptoms had disappeared - one month after the end of the treatment.

\section{METHODS}

Clinical examination, SPT to common allergens including tree and grass pollens, Dermatophagoides pteronyssinus, Dermatophagoides farinae, feathers, moulds, tomato and chocolate allergens (Allergopharma, Germany) were performed. Also the SPT (1\% concentration), as well as patch test (Chemotechnique Diagnostics, Vellinge, Sweden) to PPD were conducted. Total serum IgE was evaluated using the Uni-CAP system (Pharmacia Diagnostics, Uppsala, Sweden). Clinical signs of ocular allergy were evaluated using standardized grading system for measurement of signs and symptoms of allergic conjunctivitis described by Abelson [1]; the redness, lid swelling, chemosis, tearing and itching were evaluated. Moreover, conjunctival tear fluid was collected using microcapillary tubes (Bayer, Tarrytown, NY) and spread on glass slides, air-dried and next stained with May Grunwald Giemsa dye.

\section{RESULTS}

Physical examination revealed prominent edema of the upper part of the face including forehead, cheeks and eyes causing severe narrowing of the palpebral chink (Photo 1 and 2). According the Abelson scale [1], the redness and swelling of the eyelids and the conjunctiva and itching were evaluated at 3 scores, while tearing at 2 scores. In the slit lamp, a papillary reaction in the eyelid conjunctiva was visible, whereas mucous secretion was found in the conjunctiva folds. Skin prick tests with common allergens were positive for Dermatophagoides pteronyssinus $(5 \times 30 \mathrm{~mm}$ wheal and erythema response while the histamine reaction was $4 \times 2 \mathrm{~mm}$ and control $0 \times 0 \mathrm{~mm}$ ), Dermatophagoides

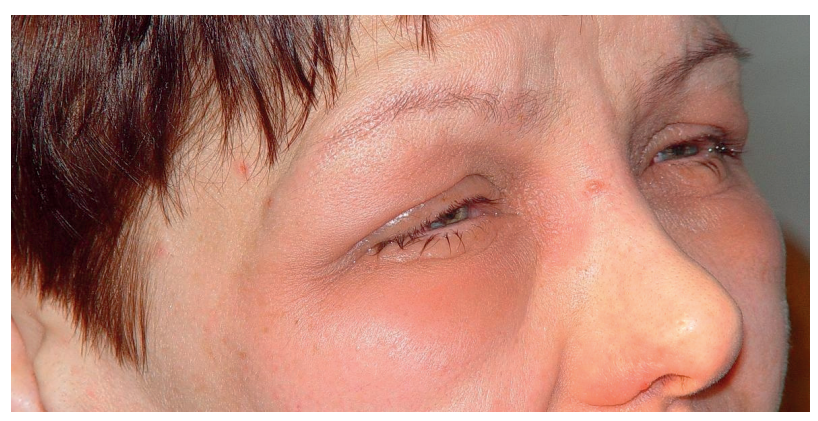

Photo 1. Contact blepharoconjunctivitis due to black henna

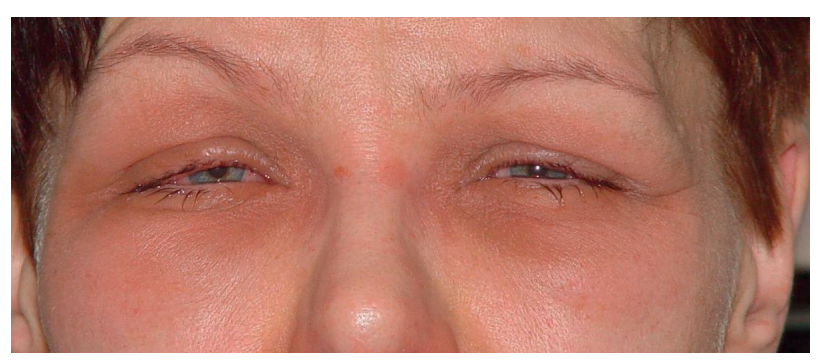

Photo 2. Contact blepharoconjunctivitis due to black henna 


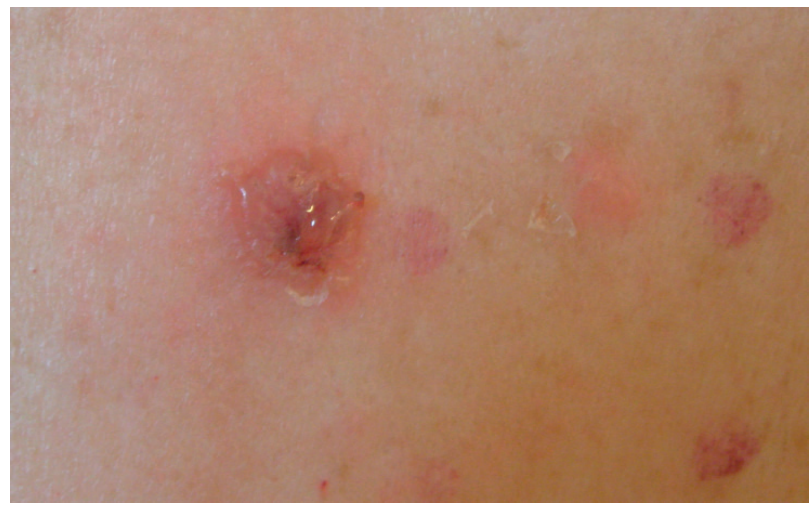

Photo 3. Positive patch test to PPD

Table 1. Cellular analysis of patient's tear fluid

\begin{tabular}{lcc}
\hline \multirow{2}{*}{ Type of cells } & \multicolumn{2}{c}{ Cell proportion in tears (\%) } \\
\cline { 2 - 3 } & $\begin{array}{c}\text { during ocular } \\
\text { symptoms }\end{array}$ & $\begin{array}{c}\text { after retreat of ocular } \\
\text { symptoms }\end{array}$ \\
\hline Epithelial & 10 & 58 \\
Neutrophils & 38 & 41 \\
Eosinophils & 25 & 1 \\
Basophils & 1 & 0 \\
Lymphocytes & 25 & 0 \\
Monocytes & 1 & 0 \\
\hline
\end{tabular}

farinae $(5 \times 30 \mathrm{~mm})$ and moulds $(3 \times 15 \mathrm{~mm})$. The total $\mathrm{IgE}$ level was $126.32 \mathrm{Ul} / \mathrm{ml}$. The SPT with PPD was negative $(0 \times 0 \mathrm{~mm})$, whereas patch test to PPD was positive (reaction after 48 hours ++ ; after 72 hours +++ ) (Photo 3 ). Table 1 gives the results of cellular analysis of tear fluid in the patient during eye symptoms and afterwards.

\section{DISCUSSION}

Periocular contact dermatitis may occur as contact conjunctivitis, allergic and/or irritative eyelid, periorbital dermatitis, or as a combination of these symptoms [2]. Temesvári et al. [2] studied a cohort of four hundred one patients with symptoms of periocular dermatitis and found contact hypersensitivity to PPD in $3.7 \%$ of subjects. However, contact blepharoconjunctivitis due to PPD has been described rarely and only as case reports [3-5]. To our knowledge, this is the first case of PPD-induced CB with concomitant increased eosinophilia in the tear fluid.

In order to confirm the diagnosis of allergic contact dermatitis, two criteria should be fulfilled: demonstration of contact allergy by a positive patch test with a nonirritant concentration of the contact allergen and demonstration of clinical relevance of the positive test by exposure history in combination with the dermatitis pattern [6]. However, in our patient, the final clinical diagnosis was difficult to establish. Admittedly, the contact allergy due to PPD was confirmed by patch testing and also typical localization of symptoms supported CB diagnosis, but the symptoms appeared about twelve hours after exposure to PPD and significant eosinophilia was found in the tear fluid. That is why the diagnosis of acute conjunctivitis seemed to be more pertinent. On the other hand, fast progress of symptoms was previously described, for example development of a severe symmetrical blepharoconjunctivitis only $2 \mathrm{~h}$ after instillations of eyedrops containing phenylephrine [7]. When the symptoms appear soon after exposure, the allergic reactions may be mistaken as immediate-type allergic reactions, while actually they represent delayed, cell-mediated hypersensitivity reaction [7].

Our patient was not exposed to sensitizing airborne allergens before the episode of blepharoconjunctivitis; therefore, the henna was suspected as a causative agent. Assessment of sensitization was the essential part of the diagnostic process. It included not only patch testing but also skin tests. SPT to PPD was negative and it entailed unlikely immediate allergic reactions, e.g. acute allergic conjunctivitis. Additionally, it is important to note that in this case the SPT to mite and mould allergens were positive whereas the patient did not report any chronic allergy symptoms. It seems that the patient's atopic status did not contribute to the eosinophilia as eosinophils vanished from the tear fluid after ocular symptoms had disappeared. 
Our patient reported presence of periodic urticarial skin symptoms after intake of certain food, although the hypersensitivity to tomato and chocolate allergens was not confirmed during skin prick testing. In contrast, she had never experienced an allergic-like reaction to the hair dye. Patients with stronger reactions to PPD are significantly more likely to have a clear history of reacting to normal consumer hair dye. They are less likely to be still dyeing their hair. Also individuals allergic to PPD have a significant frequency of simultaneous sensitivity to chemically related clothing dyes [8].

The increased eosinophilia in the tear fluid was an unexpected finding. However, in ocular allergy, the allergic reactions may involve more than one type of immunological response. The eosinophils have been found on the conjunctiva of patients with all types of ocular allergy, but not on the normal ones. It must be emphasized that $25 \%$ of eosinophilia in the tear fluid represents a very high level. There are divergent opinions regarding presence of eosinophils during $\mathrm{CB}$. It is postulated that the infiltration of lymphocytes and monocytes is the predominant feature of CB [9], but other authors reported dendritic cells, basophils, eosinophils and $\mathrm{Th}_{1}$-lymphocytes in ocular contact allergy [10].

In our patient, the final diagnosis of contact blepharoconjunctivitis due to black henna was based on the clinical signs and symptoms related to the history of exposure, together with confirmation of contact allergy to PPD while assuming that increased eosinophilia in the tear fluid resulted from complex immunologic reactions.

\section{REFERENCES}

1. Abelson MB, George MA, Schaefer K, Smith LM. Evaluation of the new ophthalmic antihistamine, $0.05 \%$ levocabastine, in the clinical allergen challenge model of allergic conjunctivitis. J Allergy Clin Immunol 1994;94:458-64.

2. Temesvári E, Pónyai G, Németh I, Hidvégi B, Sas A, Kárpáti S. Periocular dermatitis: A report of 401 patients. J Eur Acad Dermatol Venereol 2009;23(2):124-8.

3. Awan MA, Lockington D, Ramaesh K. Severe allergic blepharoconjunctivitis after eyelash colouring. Eye (Lond) 2010;24:200-1.

4. Hansson C, Thorneby-Andersson K. Allergic contact dermatitis from 2-chloro-p-phenylenediamine in a cream dye for eyelashes and eyebrows. Contact Dermatitis 2001;45:235-6.

5. Teixeira M, de Wachter L, Ronsyn E, Goossens A. Contact allergy to para-phenylenediamine in a permanent eyelash dye. Contact Dermatitis 2006;55:92-4.

6. Mortz Ch., Andersen K. New aspects in allergic contact dermatitis. Curr Opin Allergy Clin Immunol 2008;8:428-32.

7. Raison-Peyron N, Du Thanh A, Demoly P, Guillot B. Longlasting allergic contact blepharoconjunctivitis to phenylephrine eyedrops. Allergy 2009;64(4):657-8.

8. McFadden JP, Yeo L, White JL. Clinical and experimental aspects of allergic contact dermatitis to para-phenylenediamine. Clin Dermatol 2011;29(3):316-24.

9. Bielory L. Allergic and immunologic disorders of the eye. Part II: Ocular allergy. J Allergy Clin Immunol 2000;106:1019-32.

10. Chigbu DI. The pathophysiology of ocular allergy: A review. Contact Lens Anter Eye 2009;32:3-15.

This work is available in Open Access model and licensed under a Creative Commons Attribution-NonCommercial 3.0 Poland License - http://creativecommons.org/ licenses/by-nc/3.0/pl/deed.en. 